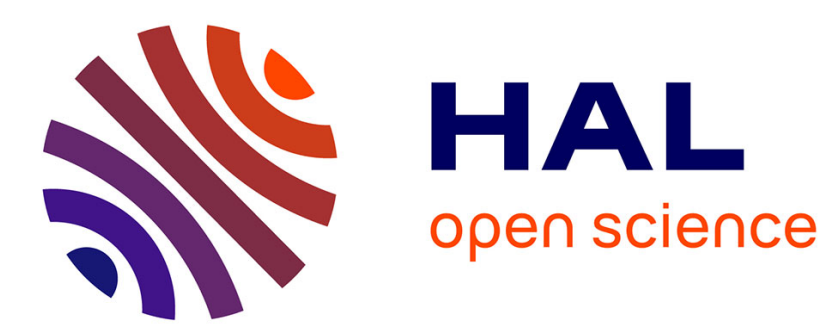

\title{
A Sheep in Wolff's Clothing: Émilie du Châtelet and the Encyclopédie
}

\author{
Glenn Roe
}

\section{To cite this version:}

Glenn Roe. A Sheep in Wolff's Clothing: Émilie du Châtelet and the Encyclopédie. Eighteenthcentury studies, 2017, 51 (2), pp.179-196. 10.1353/ecs.2017.0059 . hal-03209298

\section{HAL Id: hal-03209298 \\ https://hal.science/hal-03209298}

Submitted on 27 Apr 2021

HAL is a multi-disciplinary open access archive for the deposit and dissemination of scientific research documents, whether they are published or not. The documents may come from teaching and research institutions in France or abroad, or from public or private research centers.
L'archive ouverte pluridisciplinaire HAL, est destinée au dépôt et à la diffusion de documents scientifiques de niveau recherche, publiés ou non, émanant des établissements d'enseignement et de recherche français ou étrangers, des laboratoires publics ou privés. 


\section{A Sheep in Wolff's Clothing: ÉMILIE DU CHÂTELET AND THE ENCYCLOPÉDIE}

\section{Glenn Roe}

Émilie Du Châtelet (1706-1749)_“daring genius of the Enlightenment,” according to a recent book by Judith P. Zinsser—casts a long, if largely overlooked, shadow on the intellectual history of the mid-eighteenth century. While her various accomplishments, as a noted mathematician, natural philosopher, translator of Newton, intellectual successor of Leibniz and Wolff, companion to Voltaire, etc., certainly warrant a renewed interest in her complicated legacy, she has never been, at least until recently, considered as a possible contributor to the great mid-century Encyclopédie. No mention of Du Châtelet is made in either Diderot's "Prospectus" (1750) or d'Alembert's "Discours préliminaire" (1751), or indeed in any of the other paratexts (avertissements, errata, etc.) that accompanied the Encyclopédie's publication. ${ }^{1}$ Logically then, she is also not to be found in any of the exhaustive lists and inventories of encyclopedic authors compiled by later scholars such as Richard Schwab and Frank Kafker. ${ }^{2}$ A cursory glance at the online Encyclopédie reveals that, despite Diderot and d'Alembert's professed admiration for Du Châtelet and her work, her name appears only a handful of times over the entire seventeen volumes of text published between 1751 and 1765, and almost always in reference to her 1740 work the Institutions de physique. ${ }^{3}$ This article thus aims to establish a better understanding of the often unacknowledged relationship between these two seminal Enlightenment texts. Using new computational methods developed in the growing field of Digital Humanities, I attempt to uncover the various manners

Glenn Roe is senior lecturer in the Centre for Digital Humanities Research at the Australian National University, where his work explores the intersection of new digital methods and French literary, intellectual, and book history. A first version of this article was given as part of an Émilie Du Châtelet workshop organized by the Besterman Centre for the Enlightenment at the University of Oxford. He would like to thank Nicholas Cronk for the invitation to speak at this event as well as for his invaluable input during the early stages of this project. 
in which Du Châtelet's work is used by the encyclopédistes, who, as we shall see, both amplified and muted her authorial voice over the pages of their philosophical dictionary.

Conceived initially as an introduction to Isaac Newton's physics for her young son, Du Châtelet's Institutions de physique became a defining text for the intellectual history of the 1740s. Like Voltaire before her, Du Châtelet's attempt at explaining Newtonian physics came at a time when, in France at least, most members of the Académie des sciences had come to accept much of Newton's description of the universe, from his mathematics and optics to his more controversial notion of universal gravitation. ${ }^{4}$ There was, however, still much debate concerning Newton's mathematical formulas and how, exactly, gravity worked among the planets. Writers who concerned themselves with the topic thus had to, at some point, make a choice as to how fully they would subscribe to the Newtonian model. Most followed Voltaire's lead in his Eléments de la philosophie de Newton (1738)—written while living with Du Châtelet at her Château in Cirey from 1734 to 1749 - and were content to sound sufficiently Newtonian while simply describing the mechanics of the universe. D'Alembert's Traité de dynamique (1743) and Alexis Clairaut's Théorie de la lune (1752) are obvious examples of the sort, wherein larger questions of causation, or, what would later come to be labeled derisively as "metaphysical" questions, are left largely untreated. Voltaire shared this aversion to the metaphysical and indeed derided Du Châtelet's efforts in the Institutions de physique to go beyond pure description and to look for causes-i.e., to explain what, exactly, made gravity work on such a large scale and how such a system came into being. The great innovation of Du Châtelet's Institutions, then, is to be found in her bold willingness to leverage Gottfried Wilhelm Leibniz's metaphysical system in order to better explain Newtonian mechanics. ${ }^{5}$

A contemporary of Newton, Leibniz filtered into France with the publication of the Leibniz-Clarke correspondence in $1720 .{ }^{6}$ For Du Châtelet, Leibniz, along with his disciple Christian Wolff, offered answers to the big metaphysical questions she wished to explore in the Institutions, leading her to do with Leibniz and Wolff what others had previously done with Descartes and Newton: i.e., to create her own philosophical synthesis based on separate parts of their ideas. ${ }^{7}$ The aim of Du Châtelet's work was thus to move beyond the black-and-white, either/ or manner in which Newton and Descartes were discussed in France, and to serve as a necessary corrective to the general rejection of Leibniz by the French scientific establishment of the period. In her desire to find some truth among all these dissenting voices, it was important for Du Châtelet to understand how individuals can be certain about what it is they know. She thus adapted Leibniz and Wolff's ideas in order to establish the "certainty" of the Newtonian model of the universe over the pages of the Institutions. These broad metaphysical questions touched on a variety of different categories of thought and modes of knowing, from metaphysics, mathematics, and mechanics, to geometry and physics, which were all, for Du Châtelet and her contemporaries, part and parcel of the "natural philosophy."

It is surprising then, given the importance of Du Châtelet's magnum opus and the big questions it sought to answer, that it is does not figure more prominently in the pages of the Encyclopédie. In his article NEWTONIANISME, ou Philosophie Newtonienne, d'Alembert briefly praises Du Châtelet for her significant contribu- 
tions as a commentator and translator of Newton's ideas, though he stops short of suggesting any original contribution on her part. And yet, as Judith P. Zinsser has recently claimed, “others who wrote for them [Diderot and d'Alembert] simply took whole passages from the Institutions for subjects as general as 'Time' and 'Hypothesis' and as specific as the descriptions of the metaphysical concepts of Leibniz and Wolff. Few identified the original author, and so Du Châtelet acquired the title of so many other women before and after her: 'anonymous." "9 In fact, there are only two articles we know of in the Encyclopédie authored by a woman, both on the subject of fashion- FALBALA and FONTANGE. In each case attribution is given only anonymously by Diderot in the "Avertissement" to volume six. ${ }^{10}$

The accepted wisdom over the past 250 years, then, was that of Du Châtelet as just another missing, if not muted, female voice in the pages of the Encyclopédie. This over-simplified view has recently been brought into question thanks to renewed interest in Du Châtelet not merely as a translator, commentator, or companion of great men, but equally as a significant intellectual force in her own right. ${ }^{11}$ More specifically, recent articles by Koffi Maglo and Khan Dao Duc have succeeded in challenging what had for centuries been assumed as Du Châtelet's decidedly minor role in the encyclopedic enterprise. ${ }^{12}$ The present study thus aims to build productively off of this growing base of Du Châtelet scholarship through the use of new digital humanities tools and resources. By uncovering traces-some hidden and others in plain sight-of Du Châtelet's influence and intellectual voice in the Encyclopédie, my goal is to resituate and re-evaluate the status of Émilie Du Châtelet both as an encyclopédiste in her own right and as a key authorial contributor to the philosophic conversation that the Encyclopédie enacts.

\section{AUTHORSHIP AND AUTHORITY IN THE ENCYCLOPÉDIE}

Authorship is a thorny issue when it comes to the Encyclopédie. With over 130 contributors and a far from linear publication history, the exact dimensions of the Encyclopédie's authorial space has been heavily debated by scholars over the past half century, if not longer. ${ }^{13}$ While this article is concerned with Émilie Du Châtelet's presence and participation in the Encyclopédie, it is first necessary to think a bit more broadly about the very category of authorship itself in the Encyclopédie and how it, in many cases, becomes a function of the multifaceted system of references (both acknowledged and unacknowledged) that are woven together by its various contributors. The interplay of these intertextual references makes the Encyclopédie a much more dialogical space than one normally assumes, a site of conversation and controversy in which source material and editorial commentary are given equal, though by no means equitable, weighting.

From a practical standpoint, this underlying multivocality means that there are often at least three separate authorial, or rather dialogical, functions at play in the Encyclopédie for any given article. The first of these functions concerns the article as such, which includes the contribution of one, or sometimes several, writers on a particular subject. Second, there are the various outside sources with which these contributors marshal evidence for and against the topic of their article. As Dan Edelstein, Robert Morrissey, and I have recently shown, there is a complex system of citation and non-citation at play in the Encyclopédie: references fall anywhere 
on the spectrum from full chapter-and-verse citations; more "worldly" indications that attest to a common shared culture ("comme dit un beau génie de ce siècle," for example); and finally, a fully-formed politics of non-citation for dangerous or subversive works. ${ }^{14}$ Alongside these layers of authorship and authority, there is often an additional editorial layer at work in many articles, wherein Diderot and d'Alembert at times intervene, offering correctives or commentary, and engage in a sort of conversation. This form of dialogism is often aimed not at the contributors themselves, but rather at their various sources, or indeed with the general ideas these sources are seen to embody.

Nowhere, perhaps, is this tripartite dialogical system more prominent than in the multiple contributions of Johann Heinrich Samuel Formey (1711-1797) to the Encyclopédie, contributions that for the most part predated the editorial engagement of Diderot and d'Alembert and thus represented inherited material not wholly in phase with their philosophical ambitions. ${ }^{15}$ In order to unravel Émilie Du Châtelet's role as an encyclopédiste, and in particular the extent to which her Institutions de physique was incorporated into the text of the Encyclopédie, one must first turn to Formey's articles on metaphysics. Indeed, Formey, according to Zinsser, "is presumed to have written many of the articles in the Encyclopédie that used the Institutions," 16 an assessment that is in harmony with Koffi Maglo's more recent assertion that if one follows "les traces de Formey et vous serez en compagnie de Mme Du Châtelet" ["the traces of Formey [...] you will find yourself in the company of Mme Du Châtelet." $]^{17}$ The possible connection between Formey and Du Châtelet was first explored by Sonia Carboncini through the bias of Christian Wolff's presence in several anonymous Encyclopédie articles, though here the treatment of Du Châtelet is somewhat secondary. ${ }^{18}$ This article is thus an attempt to verify and expand upon these statements, evaluating to what extent Formey used Du Châtelet as a source-at times acknowledged, and at others not-and then examining how Du Châtelet's textual presence, whether mediated through Formey or others, can be considered an important, albeit largely overlooked, contribution to the philosophical debates enacted in the Encyclopédie.

\section{SAMUEL FORMEY, ENCYCLOPÉDISTE ANTI-PHILOSOPHE}

Formey was a Huguenot pastor of French extraction who spent his entire life in Berlin, most notably as the historiographer and then perpetual secretary of the Academy of Berlin after its reorganization by Frederick the Great in the 1740s. ${ }^{19}$ Appointed to the Royal Society in 1750, from 1741 to 1753 he gained some renown through the extended publication of his pedagogical work La Belle Wolfienne, which was meant to promote the philosophy of Christian Wolff to young women. While far from a success either commercially or philosophically, Formey's work was nonetheless important for diffusing_along with Du Châtelet's Institutions de physique published in 1740 - the ideas of both Wolff and Leibniz to the general French reading public. ${ }^{20}$ Formey's desire to write about Wolff for French readers in the style of letters to a young woman was almost certainly inspired by the earlier successes of Fontenelle's Entretiens sur la pluralité des mondes (1686), which explained the Cartesian universe, and Algarotti's Neutonianismo per le dame (1737), that set out to explain Newton's, both of which equally serve as precursors 
to Du Châtelet's intended pedagogical goals for her Institutions de physique. As we shall see, Formey relies heavily on Du Châtelet's work for his contributions to the Encyclopédie, a fact that suggests a more direct relationship of influence between the Institutions de physique and La Belle Wolfienne, though this is a connection that lies beyond the confines of this study. The scope and scale of Formey's direct involvement in the Encyclopédie project will be touched upon later, but first it is important to sketch briefly his role in the various other philosophical conversations-enacted in this case on the larger scale of the transnational Republic of Letters - to which he contributed in the second half of the eighteenth century.

A prodigious letter writer-his correspondence supposedly rivalled that of Leibniz ${ }^{21}$-Formey was in many ways representative of the moderate or mainstream strain of the Enlightenment, opposed to the more "radical" currents that would shape philosophical thought in the years following the Encyclopédie's publication, according to Jonathan Israel. ${ }^{22}$ Formey's idea of philosophy was thus, like Émilie Du Châtelet's, more expansive than the narrow definition we tend to give it today. In his particular case, Formey sought to enlighten his readers with a deft admixture of Wolffian metaphysics, philosophical Protestantism, and Cartesian rationalism, positions that would all, to some degree, come under attack by the encyclopédistes. ${ }^{23}$ As such, and despite his involvement in the encyclopedic enterprise, however tepid his engagement may have been, from the mid-eighteenth century onwards he was increasingly active in decrying what he saw as the more radical and morally dangerous positions of the French philosophes. ${ }^{24}$ This specific subset of philosophical writers-those driving the Radical Enlightenment forward, according to Israel—are designated here by the French term in order to distinguish them from the broader field of natural and experimental philosophy to which Formey, Du Châtelet, and countless others belonged. ${ }^{25}$

Formey's anti-philosophe campaign began as early as 1749 with the publication of his Pensées raisonnables, a response to, and refutation of, Diderot's Pensées philosophiques published in 1746. This first pamphlet was followed closely by his Lettre de M. Gervaise Holmes contre l'auteur de la Lettre sur les avengles in 1750, another riposte aimed at the young editor of the Encyclopédie. ${ }^{26} \mathrm{~A}$ few years later, Jean-Jacques Rousseau, still firmly in the philosophe camp at this point, comes under fire for his Discours sur les sciences et les arts, which Formey counters with an Examen philosophique de la liaison réelle qu'il y a entre les sciences et les mours, published first as part of the Mémoires de l'Académie de Berlin in 1753, and then in book form in $1755 .^{27}$

Rousseau next publicly attacks Formey in 1759 for what he perceived as an unauthorized printing in Berlin of his 1756 letter to Voltaire "Sur la providence" his famous response to Voltaire's "poème sur le désastre de Lisbonne." 28 Formey responds in kind with another unauthorised collection of excerpts taken from Rousseau's Nouvelle Héloïse (all the while voicing significant moral reservations about the work in his "averstissement") in his Esprit de Julie of $1762 .{ }^{29}$ Formey moves beyond unauthorized reprinting to an outright attack on Rousseau, and in particular his 1762 publication Émile, which Formey quickly counters with the publication of his Anti-Émile (1763), a stern rebuke not only of Rousseau's pedagogical theories, but also what Formey considered his many religious and political aberrations. ${ }^{30}$ A year later, Formey will move his critique of Émile forward, going 
so far as to "remake" Rousseau's work in his own image, publishing an Émile chrétien in 1764, a text that notably replaces the "Confession de foi du vicaire Savoyard" with a more doctrinally appropriate section. ${ }^{31}$

Given the above quarrels with Diderot and Rousseau, it is perhaps surprising that Voltaire-who in the 1760s and 1770s was by far the most publically active and universally targeted of the philosophes - is spared, seemingly, the brunt of much of Formey's public critique. This will change, however, with the publication of his memoires-Souvenirs d'un citoyen-on the eve of the Revolution. Here Formey revisits the 1750s and makes it a point to offer a rather unflattering and highly critical description of Voltaire's visit to Potsdam, which allows him to furthermore condemn most of the other leading encyclopédistes, who like Voltaire, promoted unorthodox and theologically dangerous views in the pages of the great mid-century dictionary. ${ }^{32}$ This retrospective return to the early days of the Encyclopédie thus brings us back to the topic of Formey's uneven involvement with the enterprise. Indeed, the use (he would say "abuse") of Formey's original source material at the hands of Diderot, and also notably that of d'Alembert, would remain a point of contention for the last forty years of his life. ${ }^{33}$ In order to rectify these perceived slights to his character, Formey went so far as to envision a corrective "encyclopédie réduite" that was planned but never published, although much of his post-1750 encyclopedic work would find its way into several of the Encyclopédie's successors, including the Protestant Encyclopédie d'Yverdon. ${ }^{34}$

One may well ask then, how, exactly, the anti-philosophe Formey come to be a contributor at all to Diderot and d'Alembert's philosophic machine de guerre? As it so happens, in 1742 he had begun working on his own philosophical dictionary, one that would purportedly do for France what Ephraïm Chambers' Cyclopaedia had accomplished in England. ${ }^{35}$ By 1747, however, Formey had heard rumour of a French encyclopaedia project, one that took, coincidentally enough, as its starting point a translation of Chambers into French, and decided to approach its editor, then the Abbé Gua de Malves, offering his completed articles to the new enterprise. ${ }^{36}$ In early 1749 , the deal-executed by the "libraires associés" who controlled the project-was finalized, and Formey sent the editors (by then Diderot and d'Alembert) some 1800 manuscript pages (petit in folio) in exchange for 300 livres, with the added stipulation that the manuscript be returned to the author and that his contribution be acknowledged in the work's preface. Thus, Formey is dutifully mentioned in both Diderot's 1750 "Prospectus" as well as d'Alembert's 1751 "Discours préliminaire":

Voilà les richesses sur lesquelles nous pouvions compter; mais il nous en est survenu d'autres que notre entreprise doit, pour ainsi-dire, à sa bonne fortune. Ce sont des Manuscrits qui nous ont été communiqués par des Amateurs, ou fournis par des Sçavans entre lesquels nous nommerons ici M. FORMEY, Secrétaire perpétuel de l'Académie Royale des Sciences \& des Belles-Lettres de Prusse. Cet habile Académicien avoit médité un Dictionnaire, tel à peu près que le nôtre, $\&$ il nous a généreusement sacrifié la partie considérable qu'il en avoit exécuté, $\&$ dont nous ne manquerons pas de lui faire honneur. ${ }^{37}$ 
[Such are the resources upon which we could count; but thanks to the good fortune of our enterprise, so to speak, other resources have fallen to us. They include some manuscripts sent to us by amateurs or submitted by scholars, among whom we will name here M. Formey, perpetual secretary of the Royal Academy of Sciences and Belles-Lettres of Prussia. That illustrious academician had planned a dictionary almost like our own, and he has generously turned over to us the considerable part of it which he had completed, for which we will not fail to pay him due honor.]

It stands to reason, then, that the second condition of his bequest, that the manuscript be returned, was also carried out. This is in many ways a great shame for the historiography of the Encyclopédie and its publication history, as it seems most of Formey's manuscripts from this period have been lost. As such, we have no real way of comparing the original articles to their edited versions in the final text of the Encyclopédie.

We do, however, have a fairly good notion of which articles draw upon Formey's material, although there is still some disagreement as to the exact number of articles one can count as "belonging" to Formey from an authorial standpoint. The editors of the digital edition of the Encyclopédie at the University of Chicago's ARTFL Project have marked some 111 articles as being authored by Formey, for instance, though this differs somewhat from both Richard Schwab's Inventory (114 articles) and Koffi Maglo's count of around 120 (“cent vingt articles environ qu'il a signés"). ${ }^{38}$ There are multiple reasons for this discrepancy. First and foremost, it is not exactly correct to say that Formey "signed" any of the articles that have been attributed to him, but rather that his material was used by the editors in a variety of different manners. This hearkens back to the three layers of dialogism at play in the Encyclopédie alluded to earlier, all of which are exhibited to some degree when looking at Formey's articles. He is, at times, simply the author of an article: this is the case with "DÉFINITION" in Tome 4, for example, as the final reference "article de M. Formey" attests. This is not to say, however, that even these seemingly unambiguous attributions are simple; quite the contrary, in this case almost the entire article is drawn from Condillac's Essai sur l'origine des connaissances bumaines (1746), a source used without any citation whatsoever. ${ }^{39}$

In a second instance, Formey's papers are used by other authors in the Encyclopédie more or less as source material, which leads to a host of seemingly multi-authored articles, such as Mallet's ABRAXAS, which includes the note "Cet article est en grande partie tiré des Mémoires de M. Formey, Historiographe de l'Académie royale de Prusse" directly before Mallet's signature $(G) .{ }^{40}$ In this case, the article should logically be attributed solely to Mallet, rather than being identified as co-authored with Formey, though Richard Schwab tends to assign at least partial authorship to Formey for every article in which he is mentioned. ${ }^{41}$ Another example of this genre of authorship is found in the Abbé Yvon's article ATTRIBUT, which includes the more concise note "Cet article est tiré de M. Formey" preceding Yvon's authorial sign $(X)$.

At times the use of Formey is more blatantly dialogical, in that he is used strategically to move a specific argument forward or otherwise introduce new concepts, inclusions that are often marked simply with a "M. Formey" at the end of a paragraph. This is precisely the case with d'Alembert's article AREOMETRE, in 
which he engages directly with Formey as a source, or rather as a co-signatory of the article. After a short section that is presumably drawn from Formey's papers (though we have no structural indication of what is Formey and what is d'Alembert other than the brief reference "M. Formey"), d'Alembert launches into the main crux of the article that acts as both commentary and critique of the previous section. This is by and large the same short-hand citation scheme we find peppered across the Encyclopédie with regards to Ephraim Chambers, wherein paragraphs, or even whole articles, are terminated with a simple "Chambers" — though again, with no indication of what, exactly, or even approximately, comes from the English Cyclopaedia.

In a more playful way, not surprisingly, Diderot is even more pronounced in this sort of call-and-response editorial engagement, often voicing his opinion not only with the article at hand, but also on the whole class of knowledge from which it is drawn. This is the case for Formey's metaphysics article CONSERVATION, which, after an authorial reference to Formey (Article de M. Formey), ends with the unsigned remark: “C'est ainsi que dans les questions métaphysiques fort élevées, on se retrouve après bien des détours au même point d'où l'on étoit parti, $\&$ où on auroit dû rester" [And thus it is with these sorts of high metaphysical questions, one finds oneself after many detours at the same point from which one departed, and where one should have remained] —an intervention that almost certainly originated from Diderot's acerbic pen. A similar situation can be found in the article ETERNITÉ, a text whose first half is signed by the Chevalier de Jaucourt, and whose second ends with the same attribution as CONSERVATION: "Article de M. Formey.” Diderot here again intervenes after Formey's contribution, asserting that he includes the above description of the Thomist and Scotist positions on eternity: “ $1^{\circ}$ parce qu'elles appartiennent à l'histoire de la Philosophie, qui est l'objet de notre ouvrage: $2^{\circ}$ parce qu'elles servent à montrer dans quel labyrinthe on se jette, quand on veut raisonner sur ce qu'on ne conçoit pas" [firstly because they belong to the history of Philosophy, which is the object of our work; secondly because they serve to demonstrate the labyrinth into which one throws oneself when trying to reason with the inconceivable]. ${ }^{42}$

Formey thus functions in the Encyclopédie as: a) an author; b) a source for other authors; c) a dialogical partner; and then, finally, d) a source of other sources, by which I mean that the editors (and here d'Alembert is especially active) sometimes indicate the sources that Formey is drawing upon in his articles. At the end of the article AREOMETRE, for instance, d'Alembert indicates that "nous devons ces remarques à M. Formey, qui les a tirées de M. l'abbé Nollet Lect. Phys." [we owe these remarks to M. Formey, who drew them from M. l'abbé Nollet's Lect. Phys.] ${ }^{43}$ Here again, as Formey's original articles have been lost, it is difficult to say exactly how Formey uses his various sources, nor the means by which the encyclopédistes were able to identify them (were they cited in the original? deduced from reading?, etc.). Much like Ephraïm Chamber's Cyclopaedia, which served as both an inspiration and originary source for the Encyclopédie, Formey's contributions are woven throughout this massive compilation in a variety of different manners, and for seemingly different means. ${ }^{44}$ 


\section{ÉMILIE DU CHÂTELET, ENCYCLOPÉDISTE?}

This brings us then to the case of Madame Du Châtelet, who, as Maglo and Zinsser argue, in many ways enters the Encyclopédie through Formey's mediation. This is certainly the case with the seven articles that explicitly mention Du Châtelet's Institutions de physique. Though, while Maglo asserts (or rather overstates to some degree) that "practiquement dans tous les cas, il est precisé quels passages des Institutions sont copiés ou servent d'insipration" ["in virtually all cases it is indicated which passages of the Institutions are copied or serve as inspiration"], ${ }^{45}$ until now it has remained unclear to what extent Du Châtelet's text was used in these articles, or how exactly she participates in the larger dialogical space of the Encyclopédie outlined above. To redress this gap in our knowledge, we need an indication of where the Institutions de physique is used not only when it is mentioned, but also when it is not.

In order, then, to find references to Du Châtelet's work, both acknowledged and unacknowledged, I deployed a new computational method developed in the field of Digital Humanities that compares the entire text of the Encyclopédie with a version of the Institutions de physique taken from the BnF's Gallica digital library. ${ }^{46}$ And, while the text in this case is far from perfect-it includes, for instance, many errors generated by the automatic optical character recognition (OCR) process used to digitize the book-I was nonetheless able to identify a further six articles that all borrow extensively from Du Châtelet's work, but in this case with no citation or authorial mention (see Table 1). One notices immediately that all of these newly identified articles, save SUFFISANTE RAISON, are signed by Formey or Formey and d'Alembert.

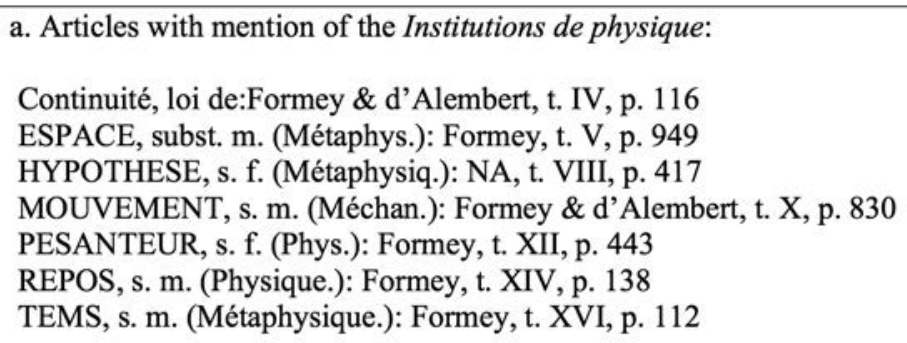

a. Articles with mention of the Institutions de physique:

Continuité, loi de:Formey \& d'Alembert, t. IV, p. 116

ESPACE, subst. m. (Métaphys.): Formey, t. V, p. 949 HYPOTHESE, s. f. (Métaphysiq.): NA, t. VIII, p. 417

MOUVEMENT, s. m. (Méchan.): Formey \& d'Alembert, t. X, p. 830

PESANTEUR, s. f. (Phys.): Formey, t. XII, p. 443

REPOS, s. m. (Physique.): Formey, t. XIV, p. 138

TEMS, s. m. (Métaphysique.): Formey, t. XVI, p. 112

b. Articles with no mention of the Institutions de physique:

CONTINU, adj. (Physiq.): Formey \& d'Alembert, t. IV, p. 115

CONTRADICTION, s. f. (Métaphys.): Formey, t. IV, p. 119

DIVISIBILITÉ, (Géom. \& Phys.): Formey \& d'Alembert, t. IV, p. 1074

PENDULE, s. m. (Méchanique.): Formey \& d'Alembert, t. XII, p. 293

Suffisante raison, (Métaphysiq.): NA, t. XV, p. 634

VITESSE, s.f. (Méchan.): Formey, t. XVII, p. 359

Table 1. Encyclopédie articles that draw from Émilie du Châtelet's Institutions de physique with and without citation. 
The above identifications are made using a technique known as "sequence alignment," a computational approach borrowed from the field of bio-informatics. ${ }^{47}$ For this project I used the PhiloLine sequence alignment package developed by the ARTFL Project at the University of Chicago, an algorithm that works in tandem with its full-text search and retrieval software PhiloLogic. ${ }^{48}$ Basically, the system treats two texts as long potential sequences, and then looks for common subsequences with a high degree of flexibility between the two (think of missing genetic information that must be skipped over in the sequencing of the human genome, for example). This technique allows us not only to identify borrowed passages that are uncited, but also to see exactly how these passages are deployed in the Encyclopédie even when cited. The article "Continuité, (loi de)" serves as a prime example of how these new approaches can help us unravel the often-complicated interplay of authorial gestures at work in the Encyclopédie. The article is signed by d'Alembert, who then claims "Nous devons cet article à M. Formey" [we owe this article to M. Formey], and which furthermore includes the reference "Lisez le chap. j. des instit. de Physiq. de Mad. Duchatelet, depuis le $\mathbb{S} 13$ jusqu'à la fin” [Read chapter I of Mme Duchatelet's Institutions de physique, from paragraph 13 until the end], an imperative command that seems, in form, much more like a renvois, or cross-reference, than a citation. ${ }^{49}$

Using the sequence alignment comparison technique, we can now, for the first time perhaps, see exactly to what extent Du Châtelet is used in this article as well as which passages are shared between the two texts. Remarkably, almost the entire article is in fact drawn from the Institutions de physique, though certainly not in the word-for-word or copy-paste manner one might assume. Instead, the article incorporates parts of paragraph $\$ 13$, to which the reference alludes, modifies the text, draws on a sentence from paragraph $\$ 14$, before moving to paragraph $\$ 17$, and then backwards to paragraph $\$ 15$ to conclude. ${ }^{50}$ Here again, this manner of manipulating source material is much more like a conversation than a rote citation, wherein Mme Du Châtelet (or is it Formey?) is used as a proxy or conceptual standin for both "les Leibnitiens" and "les partisans de ce principe [de continuité]." ${ }_{1}$

The granular level of this sort of text comparison allows us to think more broadly about the proportionality of Du Châtelet's text against the rest of the article in which it occurs. In the figure below, the total word count of the articles in blue is compared to Du Châtelet's contribution in red (see Figure 1). Obviously, longer articles such as MOVEMENT and PENDULE will yield a much lower proportion of included text, and indeed in these cases Du Châtelet can be considered one among many different sources used to construct the longer articles (though in the case of PENDULE there is no reference to her work).

We can also think about this proportionality in terms of a "score" or percentage of any given article that belongs to Du Châtelet-those of us who use plagiarism software like Turnitin to mark essays will be all too familiar with these sorts of metrics. Below we have in ascending order all of the articles identified as containing at least some of the Institutions de physique, along with their corresponding "Du Châtelet scores" (See Table 2). To return to an example that we have already seen, d'Alembert and Formey's article "Continuité, (loi de)" scores as approximately eighty-one percent Du Châtelet. This fact necessarily raises the following question: to what extent is Formey (or even d'Alembert for that matter) really the "author" of this article. 


\begin{tabular}{|l|l|}
\hline Pendule (Formey, d'Alembert) & Tems (Formey) \\
Word count: 4579 & Word count: 3361 \\
IP: 513 & IP: 2105 \\
Score: $11 \%$ & Score: $63 \%$ \\
\hline Movement (Formey, d'Alembert) & Hypothèse (NA) \\
Word count: 13056 & Word count: 1080 \\
IP: 1889 & IP: 809 \\
Score: $14 \%$ & Score: $75 \%$ \\
\hline Divisibilité (Formey, d'Alembert) & Continuité (Formey, d'Alembert) \\
Word count: 2624 & Word count: 902 \\
IP: 587 & IP: 732 \\
Score: $22 \%$ & Score: $81 \%$ \\
\hline Vitesse (Formey) & Pesanteur (Formey) \\
Word count: 1452 & Word count: 2762 \\
IP: 401 & IP: 2254 \\
Score: $28 \%(68 \%) *$ & Score: $82 \%$ \\
\hline Repos (Formey) & Suffisante raison (NA) \\
Word count: 1103 & Word count: 1331 \\
IP: 358 & IP: 1158 \\
Score: $32 \%$ & Score: $87 \%$ \\
\hline Continu (Formey, d'Alembert) & Contradiction (Formey) \\
Word count: 534 & Word count: 338 \\
IP: 238 & IP: 320 \\
Score: $45 \%(82 \%)^{*}$ & Score: $95 \%$ \\
\hline Espace (Formey) & \\
Word count: 3363 & \\
IP: 1730 & \\
Score: $51 \%$ & \\
\hline
\end{tabular}

Table 2. Articles that contain at least some text of the Institutions de physique and their percentages in ascending order.

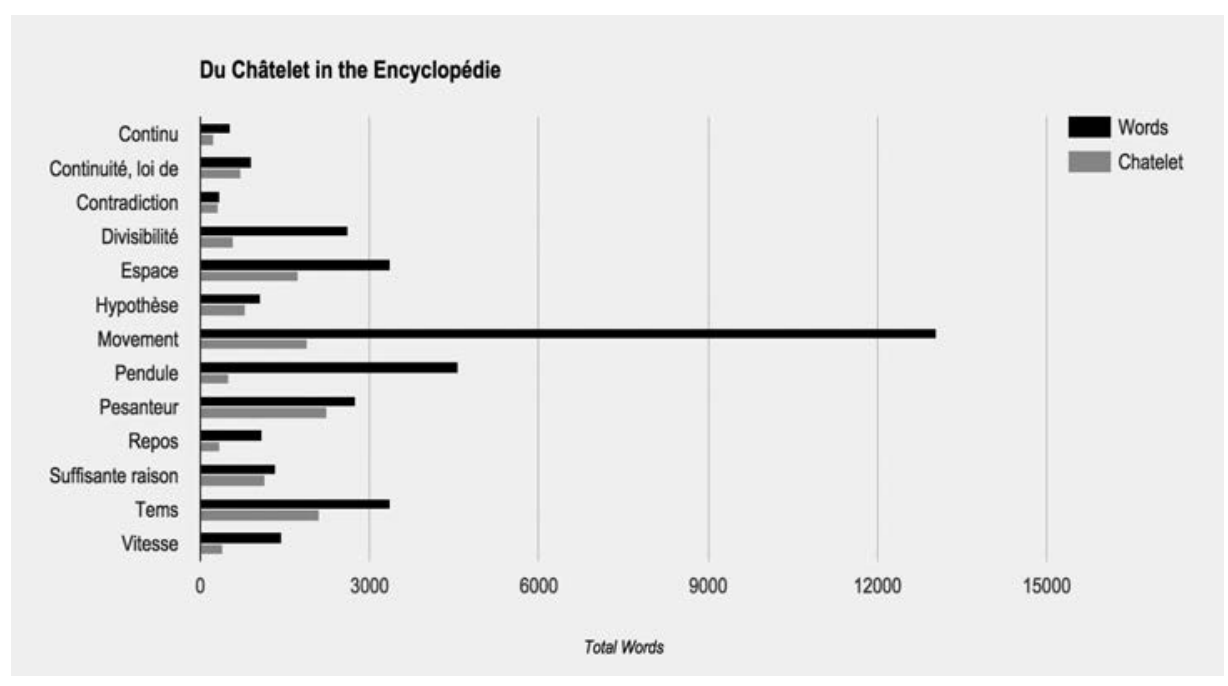

Figure 1. Total number of words compared to number of words drawn from the Institutions de physique. 
Some of these proportionality scores are variable (indicated by the *), and this is again due to the multi-vocal nature of many of the articles Formey's papers were used to construct. About forty-five percent of d'Alembert's CONTINU article, for instance, comes from the Institutions de physique (without citation). However, if we look closely, we see that CONTINU is in fact two articles, wherein the first paragraph, d'Alembert tells us, can be considered by itself an "Article de M. Formey." 52 Thus, if we score only Formey's part, the Du Châtelet percentage almost doubles, and we are again left with the obvious question as to the validity of attribution concerning Formey's inclusion as an "author" of this part of the article. A similar pattern of re-use is found in the longer articles such as PESANTEUR, which rates at an impressive eighty-two percent Du Châtelet, albeit in this case there is at least a reference to Formey's use of Du Châtelet as a source text at the end of the article (though with no indication of what part of Du Châtelet's text is used and where): "Cet article est de M. Formey, qui l'a tiré en partie des Inst. de Phys. de Mad. Du Châtelet" ["This article is from M. Formey, who extracted it in part from the Mad. Du Châtelet's Inst. de Phys."]. ${ }^{53}$ We are thus left to wonder if this information was included in Formey's original article, or whether it was added by the editors post hoc, and therefore to what extent this article should be considered an article by Madame Du Châtelet with a brief introduction by Samuel Formey, rather than its current attribution to Formey alone.

Finally, to conclude, I would like to consider the two articles with the highest Du Châtelet scores: SUFFISANTE RAISON (eighty-seven percent score) and CONTRADICTION (ninety-five percent score); the former unsigned in the Encyclopédie, and the latter attributed again to Formey. SUFFISANTE RAISON is interesting in that it quite clearly participates in the dialogical system of the Encyclopédie I lay out above, wherein the only part of the article not taken from Du Châtelet's text is in effect a counter-argument to the principle of sufficient reason as elaborated by Leibniz and Wolff and filtered through Madame Du Châtelet, although the article includes no mention of her or the Institutions de physique. Clearly, we know that one of Du Châtelet's aims in writing the Institutions was to present Leibniz's (and to a lesser degree Wolff's) ideas to the French-speaking world, and this is perhaps the case of her being too successful in her execution, as her text becomes (in this particular case at least) the unacknowledged point of departure from which the Encyclopédie can criticise Leibniz's and Wolff's metaphysics. ${ }^{54}$ It is highly probable that the penultimate paragraph of SUFFISANTE RAISON is another instance of editorial intervention, most likely from Diderot, who ceased using his authorial mark (*) in the final suppressed volumes of the Encyclopédie published en masse in 1765. Responding to the text of the Institutions-quite literally in this case, as the main body of the article includes Madame Du Châtelet's first person pronoun ' $\mathrm{Je}$ ' in its exposition-the interlocutor suggests that, if taken to its logical extreme, the doctrine of sufficient reason would lead to "spinosism." A loaded term, for sure, the evocation of Spinoza here as a counterweight to Leibniz and Wolff moves the reader subtly (and perhaps ironically) from the metaphysical to the materialistic:

Au reste, on peut faire une espece d'argument ad hominem contre le principe de la raison suffisante, en demandant à Messieurs Leibnits \& Wolf comment ils peuvent l'accorder avec la contingence de l'univers. 
La contingence en effet suppose une différence d'équilibre. Or, quoi de plus opposé à cette indifférence que le principe de la raison suffisante? Il faut donc dire que le monde existe, non contingemment, mais en vertu d'une raison suffisante, \& cet aveu pourroit mener jusqu'aux bords du spinosisme. ${ }^{55}$

[Furthermore, one can make a kind of ad hominem argument against the principle of sufficient reason by asking Messieurs Leibniz and Wolff how they can harmonize it with the contingency of the universe. A contingency implying, in effect, a difference in equilibrium. But, what is more opposed to this indifference than the principal of sufficient reason? One must then say that the world exists, not contingently, but by virtue of a sufficient reason, and this admission could very well lead to the edges of Spinozism.]

The article CONTRADICTION is less conversational in tone, primarily because there are only eighteen words that are not drawn from Du Châtelet, comprising all or most of paragraphs $\$ 4$ and $\$ 7$ from chapter one of the Institutions de physique. There are, however, two interesting cross-references included-and we know that Diderot held the system of renvois to be the most important (and indeed most dialogical) of the Encyclopédie's organisational schemes. ${ }^{56}$ There is first an indirect renvois (Voy. son Article) that refers the reader to the article SUFFISANTE RAISON (which we have just seen belongs largely to Mme Du Châtelet) along with a direct renvois to the abbé Yvon's article AXIOME, directly following the attribution of the article to Formey: "Cet article est de M. Formey, sur quoi voyez l'article AXIOME" ["This article is from M. Formey, whereupon see the article AXIOME"]. ${ }^{57}$ Following this renvois thus opens the reader up to further links through the metaphysical articles CONNAISSANCE, attributed by Schwab to Formey, with citations to John Locke, Claude Buffier, and Chambers; ABSTRACTION by César Chesneau Dumarsais; and finally ANALYSE by d'Alembert, which is decidedly less Leibnizian/Wolffian in scope and therefore acts as a critical counterbalance to Formey's (and Du Châtelet's) articles.

This brings us back, finally, to the notion of Formey as a dialogical actor, or pivot, in the Encyclopédie-an author that in many cases is used as a pretext for an argument a contrario with Leibniz and Wolff and their respective metaphysics. This is clearly Diderot's stance in CONSERVATION, as we have seen earlier, as well as the article ETERNITÉ, in which the editor effectively undermines Formey's entire contribution, noting that the article's propositions "servent à montrer dans quel labyrinthe (a favourite Diderotien metaphor) on se jette, quand on veut raisonner ce qu'on ne conçoit pas" [serve to demonstrate the labyrinth into which one throws oneself when trying to reason with the inconceivable]..$^{58}$

Though more circumspect than Diderot, d'Alembert too is not immune from this sort of editorial banter, as evidenced by his presumed intervention at the end of the Formey article ESPACE, which, as we have seen above, is in reality fiftyone percent Du Châtelet. In this case, the shared nature of the article's authorship is at least suggested at by its unusually long and precise statement of attribution: “Cet article est tiré des papiers de M. Formey, qui l'a composé en partie sur le recueil des Lettres de Clarke, Leibnitz, Newton, Amsterd. 1740, \& sur les inst. de Physique de madame Du Châtelet" [This article is drawn from the papers of $\mathrm{M}$. Formey, who composed it in part using the collected letters of Clarke, Leibniz and 
Newton (Amsterdam, 1740), and with the Institutions de physique of Madame Du Châtelet]. ${ }^{59}$ Directly following this intervention, which logically can be seen as an editorial attempt at clarifying some of Formey's uncited sources, the article closes with a unusual flourish: "Nous ne prendrons point de parti sur la question de l'espace ; on peut voir, par tout ce qui a été dit au mot Élémens des Sciences, combien cette question obscure est inutile à la Géométrie \& à la Physique" [We take no position on the question of space; one can see, by all that has ben said in the article Élémens des Sciences, how much this obscure question is useless to Geometry and Physics]. ${ }^{60}$ The implied superiority of geometry and physics above Formey's (i.e., Leibniz's, Wolff's, and Du Châtelet's) metaphysics is here quite clear, and wholly in line with d'Alembert's philosophical outlook. Furthermore, the implicit renvo $i$ to the article ELEMENS DES SCIENCES-one of d'Alembert's most important contributions-and the explicit cross-references to several more of his articles in the domains of mechanics and physics leave little doubt as to the authorship of this particular comment, and demonstrates forcefully the various layers of authorial interaction at play in the Encyclopédie.

\section{CONCLUSION}

Lost, perhaps, in the midst of these conversations for and against the metaphysical systems of Leibniz and Wolff is the active role that Madame Du Châtelet plays in their elaboration over the entirety of the Encyclopédie. The Institutions de physique is in this light much more than a mere source that Formey draws upon among others. Indeed, it is safe to say that in the majority of the cases we have outlined above, the ideas with which Diderot and d'Alembert are conversing, the clear and concise crystallizations of Wolff and Leibniz they wish to combat, come directly from the Institutions de physique and only secondarily belong to Formey, if at all. Thus, if we think again about the particular dialogical space of the Encyclopédie I have outlined above, and the philosophical conversations that are enacted therein, the traditional (and unsurprisingly male-dominated) image of Diderot and d'Alembert debating the ideas of Leibniz and Wolff through the mediation of Formey is now in need of serious reconsideration. This article is intended as a first step in this process of recalibration, and as a testament to the growing recognition of Madame Du Châtelet's importance to both the encyclopedic enterprise and the intellectual history of the eighteenth century.

What is perhaps most significant about the findings presented here, beyond Du Châtelet's role as an unacknowledged source for the Encyclopédie, is how, in a matter of just ten years, Du Châtelet had become the authority on Leibniz and Wolff in French, first for Formey and later for both Diderot and d'Alembert. Unattributed authors were used for a variety of reasons in the Encyclopédie, as we have previously demonstrated, ${ }^{61}$ so uncovering previously unseen passages of $\mathrm{Du}$ Châtelet's Institutions, while important, is by no means surprising. Nor is the fact that Diderot and d'Alembert, and behind them most other French (and English) philosophers, rejected the metaphysics of Leibniz and Wolff as a means for acquiring "certainty" about the physical universe. What is surprising, however, is the important and hitherto unacknowledged role that Du Châtelet played in framing those big questions concerning the nature of knowledge, the limits of human intellect, and the workings of the universe that the Encyclopédie itself tried to answer. 
It is perhaps time then, given the above findings, to more fully acknowledge Du Châtelet's important role as a posthumous and often unnamed contributor to the Encyclopédie. If, however, some among us are still not quite ready to grant Émilie Du Châtelet full status as an encyclopédiste, then, as a matter of principal, we need to be sure that she is at least a part of the conversation.

\section{NOTES}

1. See "Front Matter," ARTFL Encyclopédie Project, Univ. of Chicago: http://encyclopedie.uchicago. edu/node/4. Unless otherwise indicated, all references to the Encyclopédie are drawn from the online ARTFL Encyclopédie Project, Robert Morrissey and Glenn Roe, eds. (Univ. of Chicago: Spring 2016): http://encyclopedie.uchicago.edu/. Accessed 15 May 2017.

2. See Richard N. Schwab, Walter E. Rex, and John Lough, Inventory of Diderot's Encyclopédie (Oxford: Studies on Voltaire and the Eighteenth Century [hereafter SVEC], 1971-1984); Frank A. Kafker and Serena Kafker, The Encyclopedists as Individuals: A Biographical Dictionary of the Authors of the Encyclopédie (Oxford: SVEC, 1988); and Frank A. Kafker, The Encyclopedists as a Group: A Collective Biography of the Authors of the Encyclopédie (Oxford: SVEC, 1996).

3. On the Institutions de physique, see William Barber's essay "Mme Du Châtelet and Leibnizianism: the genesis of the Institutions de physique," in W.H. Barber, J.H. Brumfitt, R.A. Leigh, R. Shackelton, and S.S.B. Taylor, eds., The Age of Enlightenment: Studies Presented to Theodore Besterman (Edinburgh: Univ. Court of the Univ. of St. Andrews, 1967): 200-22; as well as Judith P. Zinsser and Julie Candler Hayes, "Rereading W. H. Barber," in Judith P. Zinsser and Julie Chandler Hayes, eds., Émilie Du Châtelet: Rewriting Enlightenment Philosophy and Science (Oxford: SVEC, 2006), which in many ways supersedes Barber's earlier assertions.

4. See J.B. Shank, The Newton Wars and the Beginning of the French Enlightenment (Chicago: Univ. of Chicago Press, 2008).

5. Shank, The Newton Wars, 403-80.

6. Recueil de pièces diverses sur la philosophie la religion et l'histoire par Leibniz, Clarke et Newton (Amsterdam: Pierre Desmaizeau, 1720).

7. On the intellectual importance of the Institutions, see the "Editor's Introduction" to Émilie Du Châtelet, Selected Philosophical and Scientific Writings, ed. Judith P. Zinsser (Chicago: Univ. of Chicago Press, 2009).

8. Shank, The Newton Wars, 37-48.

9. Judith P. Zinsser, Émilie Du Châtelet: Daring Genius of the Enlightenment (New York: Penguin Books, 2006), 285.

10. "Une Femme que nous n'avons pas l'honneur de connoître, nous a envoyé les articles FALBALA, FONTANGE, \& autres." Diderot, "Avertissement," Encyclopédie, 6:6. The ARTFL database refers to this author as "Anonymous woman," while John Lough believes the author to be the Marquise de Jaucourt, Marie de Vivens. See Lough, Essays on the Encyclopédie of Diderot and D'Alembert (Oxford: Oxford Univ. Press, 1968), 479.

11. See for instance, Zinsser and Hayes, eds., Émilie Du Châtelet and Ruth Hagengruber, ed., Émilie Du Châtelet: Between Leibniz and Newton (London: Springer, 2011).

12. See Koffi Maglo, "Madame Du Châtelet, l'Encyclopédie et la philosophie des sciences," in Ulla Kölving and Olivier Courcelle, eds., Emilie Du Châtelet: éclairages et documents nouveaux (Paris, Ferney-Voltaire: Centre international d'étude du XVIIIe siècle, 2008), 255-66, and Khanh Dao Duc, “Leibniz dans l'Encyclopédie," Recherches sur Diderot et sur l’Encyclopédie 48 (2013): 123-42.

13. On the Encyclopédie authors, see Schwab et al., Inventory of Diderot's Encyclopédie and Kafker, The Encyclopédistes as Individuals. On the Encyclopédie's publication history, see John Lough, The Encyclopédie (Geneva: Slatkine, 1989). 
14. See Dan Edelstein, Robert Morrissey, and Glenn Roe, "To Quote or Not to Quote: Citation strategies in the 'Encyclopédie,'” Journal of the History of Ideas 74, no. 2 (April 2013): 213-36.

15. See Georges Roth, "Samuel Formey et son projet d'Encyclopédie réduite," Revue d'Histoire littéraire de la France 54, no. 3 (1954): 371-74.

16. Zinsser, Émilie Du Châtelet, 349, n. 96.

17. Maglo, "Mme Du Châtelet," 262.

18. Sonia Carboncini, "L'Encyclopédie et Christian Wolff. A propos de quelques articles anonymes," Les Etudes Philosophiques 4 (1987): 489-504.

19. See Kafker and E. Marcu, “Un Encyclopédiste oublié: Formey,” Revue d'Histoire littéraire de la France 53, no. 3 (1953): 296-305.

20. See Johann Heinrich Samuel Formey, La Belle Wolfienne, 6 vols. (La Haye: C. LeVier 1741-1753); and Anne-Lyse Rey, "Les Monades selon Samuel Formey," Studia Leibnitiana 45, no. 2 (2013): 135-49.

21. See Werner Krauss, "La Correspondance de Formey,” Revue d'Histoire littéraire de la France 63, no. 2 (1963): 207-16; and André Bandelier, "Sur la correspondance de Jean-Henri-Samuel Formey," in Benoît Melançon, ed., Penser la lettre: Actes du colloque d'Azay-le-Ferron (mai 1997) (Québec: Fides, 1998).

22. See Jonathan Israel, Radical Enlightenment: Philosophy and the Making of Modernity 1650-1750 (Oxford: Oxford Univ. Press, 2002) and Democratic Enlightenment: Philosophy, Revolution, and Human Rights, 1750-1790 (Oxford: Oxford Univ. Press, 2013). For an alternative view on Israel's historiography, see Antoine Lilti, “Comment écrit-on l'histoire intellectuelle des Lumières? Spinozisme, radicalisme et philosophie,” Annales. Histoire, Sciences Sociales 64, no. 1 (2009): 171-206.

23. For more on Formey's philosophical engagements, see Margarete G. Smith, "In defence of an eighteenth-century academician, philosopher and journalist: Jean-Henri-Samuel Formey," in Studies on Voltaire and the Eighteenth Century 311 (1993): 93-108.

24. See Annett Volmer, "Journalismus und Aufklärung: Jean Henri Samuel Formey und die Entwicklung der Zeitschrift zum Medium der Kritik," Jabrbuch Für Kommunikationsgeschichte 9 (2007): 101-29.

25. On the persistence and impact of natural philosophy on the Enlightenment, see Margaret C. Jacob, The Cultural Meaning of the Scientific Revolution (Philadelphia: Temple Univ. Press, 1988) and Shank, The Newton Wars.

26. Formey, Pensées raisonnables opposées aux "Pensées philosophiques", avec un essai de critique sur le livre intitulé : "les Moeurs" et la lettre de Gervaise Holmes à l'auteur de celle sur les aveugles, par M. Formey (Göttingue et Leide: E. Luzac fils, 1756).

27. Formey, Examen philosophique de la liaison réelle qu'il y a entre les sciences \& les mours... (Paris: Antoine-Claude Briasson, 1755).

28. George R. Havens, "Voltaire, Rousseau, and the "Lettre sur la Providence," Publications of the Modern Language Association of America 59, no. 1 (March 1944): 109-30.

29. Formey, L'Esprit de Julie, ou extrait de "la Nouvelle Héloïse," ouvrage utile à la société et particulièrement à la jeunesse, par M. Formey (Berlin: J. Jasperd, 1763).

30. Formey, Anti-Émile (Berlin: J. Pauli, 1763).

31. Formey, Émile chrétien, consacré à l'utlité publique (Berlin: J. Neaulme, 1764). See also Sébastien Charles, "Le Bon Sens face à l'utopie: Formey juge de Jean-Jacques, ou l'Emile revisité," Studi Francesi 46, no. 3 (2002): 606-18.

32. Formey, Souvenirs d'un citoyen, 2 vols. (Berlin: F. de La Garde, 1789).

33. See François Moureau, "L'Encyclopédie d'après les correspondants de Formey," Recherches sur Diderot et sur l'Encyclopédie 3 (October 1987): 125-45. 
34. See Roth, "Samuel Formey et son projet d'Encyclopédie réduite,"” and David J. Adams, "Formey continuateur de l'Encyclopédie," Recherches sur Diderot et sur l'Encyclopédie 13, no. 1 (1992): 117-29.

35. See Correspondance passive de Formey: lettres adressées à Jean-Henri-Samuel Formey, 1739-1770 (Genève: Slatkine, 1996).

36. Frank A. Kafker, “Gua de Malves and the 'Encyclopédie,”” Diderot Studies 19 (1978): 93-102.

37. Jean le Rond d'Alembert, “Discours préliminaire," in Encyclopédie, 1:33. Translation: "Preliminary Discourse," The Encyclopedia of Diderot \& d'Alembert Collaborative Translation Project, trans. Richard N. Schwab and Walter E. Rex (Ann Arbor: Michigan Publishing, Univ. of Michigan Library, 2009). http://hdl.handle.net/2027/spo.did2222.0001.083. Accessed 25 October 2016.

38. See Schwab, Inventory, 100-101 and Maglo, "Mme Du Châtelet," 255.

39. My thanks to Alexander Bocast for alerting me to Condillac's presence in this particular article. See his recent work Chambers on Definition (McLean: Berkeley Bridge Press, 2016).

40. Mallet, “ABRAXAS,” Encyclopédie, 1:34-35.

41. Schwab, Inventory, 100-101.

42. Jaucourt, Formey, Diderot, “ETERNITÉ,” Encyclopédie, 6:48.

43. D’Alembert, “AREOMETRE,” Encyclopédie, 1:632.

44. On Chambers' use as an intermediary source for the Encyclopédie, see Alain Cernuschi, "La Cyclopedia, un intermédiaire entre les Mémoires de l'Académie des sciences et l'Encyclopédie," Recherches sur Diderot et sur l'Encyclopédie 45 (2010): 131-45.

45. Maglo, “Mme Du Châtelet,” 255.

46. Gabrielle-Émilie Le Tonnelier de Breteuil Du Châtelet, Institutions de physique (Paris: Prault fils, 1740). http://catalogue.bnf.fr/ark:/12148/cb30363544v. Accessed 25 October 2016. All of Du Châtelet's writings (except the second edition of the Institutions and the 1744 printing of her essay on fire) are available at: http://womeninscience.history.msu.edu/.

47. For a general introduction to sequence alignment algorithms, see Dan Gusfield, Algorithms on Strings, Trees, and Sequences (Cambridge: Cambridge Univ. Press, 1997); on one of the most widely used sequence alignment algorithms, see Stephen F. Altschul, Warren Gish, Webb Miller, et al., "Basic Local Alignment Search Tool," The Journal of Molecular Biology 215 (1990): 403-10; and on a more recent use of the sequence alignment applied to literary texts, see Jean-Gabriel Ganascia, Pierre Glaudes, and Andrea Del Lungo, "Automatic detection of reuses and citations in literary texts," Literary and Linguistic Computing 29, no. 3 (2014): 412-21.

48. See Russell Horton, Mark Olsen, and Glenn Roe, "Something Borrowed: Sequence Alignment and the Identification of Similar Passages in Large Text Collections," Digital Studies / Le champ numérique 2, no. 1 (2010): https://www.digitalstudies.org/ojs/index.php/digital_studies/article/view/190/235. Accessed 15 May 2017. Information on PhiloLine can be found here: https://code.google.com/archive/p/ text-pair/ and the source code for PhiloLogic3 is available here: https://sites.google.com/site/philologic3/ home.

49. D’Alembert and Formey, “Continuité, (loi de)," Encyclopédie, 4:117.

50. Du Châtelet, Institutions de physique, 30-35.

51. See D’Alembert and Formey, “Continuité, (loi de)," Encyclopédie, 4:116.

52. D’Alembert, “CONTINU,” Encyclopédie, 4:115.

53. Formey, “PESANTEUR,” Encyclopédie, 12:446.

54. On Leibniz, Wolff, and Du Châtelet in the Encyclopédie, see Khanh Dao Duc, "Leibniz dans l'Encyclopédie."

55. “Suffisante raison,” Encyclopédie, 15:635 [translation my own]. 
56. On the cross-reference scheme in the Encyclopédie, see Gilles Blanchard and Mark Olsen, "Le système de renvois dans L'Encyclopédie: une cartographie de la structure des connaissances au XVIIIème siècle," Recherches sur Diderot et sur l'Encyclopédie 31-32 (2002): 45-70, and Benoît Melançon, "Sommes-nous les premiers lecteurs de l'encyclopédie?," in J.-M. Jean-Michel Salaün and C. Vandendorpe, eds., Les défis de la publication sur le Web: hyperlectures, cybertextes et méta-éditions (Lyon: Presses de l'École Nationale Supérieure des Sciences de l'Information et des Bibliothèques: 2004): $145-65$.

57. Formey, “CONTRADICTION," Encyclopédie, 4:119.

58. Jaucourt, Formey, Diderot, “ETERNITÉ,” Encyclopédie, 6:48.

59. Formey, “ESPACE,” Encyclopédie, 5:952.

60. Formey, “ESPACE,” Encyclopédie, 5:952.

61. See Edelstein, Morrissey and Roe, “To Quote or Not to Quote." 